\title{
Downregulation of transforming growth factor- $\beta$ (TGF- $\beta$ ) and vascular endothelial growth factor (VEGF) in ehrlich ascites carcinoma-bearing mice using stearic acid-grafted carboxymethyl chitosan (SA-CMC)
}

\author{
Salem A. Habib ${ }^{1 \#}$, Yassin A. Aggour ${ }^{2}$, Hossam A. Taha ${ }^{1}$ \\ ${ }^{1}$ Biochemistry Division, Chemistry Department, Damietta Faculty of Science, Mansoura University, Mansoura, Egypt; \\ \#Corresponding Author: Salem habib@yahoo.com \\ ${ }^{2}$ Chemistry Departments, Damietta Faculty of Science, Mansoura University, Mansoura, Egypt
}

Received 26 August 2012; revised 28 September 2012; accepted 10 October 2012

\begin{abstract}
The present study was conducted to investigate the use of stearic acid-grafted carboxymethyl chitosan (SA-CMC) as a downregulator for transforming growth factor- $\beta$ (TGF- $\beta$ ) and vascular endothelial growth factor (VEGF) in Ehrlich ascites carcinoma (EAC)-bearing mice. The antitumor effect of stearic acid-grafted carboxymethyl chitosan was assessed by the estimation of TGF- $\beta$ and VEGF in serum in addition to the estimation of tumor volume, median survival time (MST), percentage of increase in life span (ILS\%) as well as the contents of total lipid, DNA and RNA in liver tissues. Hematological profiles (hemoglobin, red blood cells, and platelets) were also assessed. In addition, liver function tests and the redox status were estimated. TGF- $\beta$, VEGF, DNA, RNA, and malondialdehyde (MDA) levels, in addition to serum alanine transaminase (ALT) and gamma glutamyl transferase (GGT) activities as well as total white blood cells counts and tumor volume were all highly significantly increased $(P<0.001)$ in untreated EACbearing mice compared to controls. However, hematological profiles, total lipid in liver tissues and serum albumin were highly decreased in EAC-bearing mice compared to controls. All these parameters were restored to the normal levels in SA-CMC treated EAC-bearing mice compared to the untreated EAC-bearing mice. It is thus concluded that stearic acid-grafted carboxymethyl chitosan has a remarkable antitumor activity against EAC in Swiss albino mice through down-
\end{abstract}

\footnotetext{
*The authors declare that there are no conflicts of interest.
}

regulation of TGF- $\beta$ and VEGF.

Keywords: Transforming Growth Factor- $\beta$; Vascular Endothelial Growth Factor; EAC Cells; Stearic Acid-Grafted Carboxymethyl Chitosan

\section{INTRODUCTION}

Many studies have demonstrated the role of reactive oxygen species (ROS) in tumor development [1]. ROS can be produced from endogenous sources, such as from mitochondria, peroxisomes, and inflammatory cell activation [2]; and exogenous sources, including environmental agents, pharmaceuticals, and industrial chemicals. The free radicals which include both reactive oxygen species such as, superoxide $\left(\mathrm{O}^{2-}\right)$, hydroxyl $\left(\mathrm{OH}^{-}\right)$, hydroperoxyl $\left(\mathrm{HOO}^{-}\right)$, peroxyl $\left(\mathrm{ROO}^{-}\right)$and alkoxyl $\left(\mathrm{RO}^{-}\right)$ radicals and nitrogen (RNS) species are highly active and generally unstable [3]. Many physiological functions depend on a balance between reactive species and antioxidant defenses [4]. The uncontrolled oxidative stresses due to excessive production of active oxygen or imbalance in body's redox potential have been implicated in diverse processes in various cancers, and generally the increase of ROS in cancer cells is known to play an important role in the initiation and progression of cancer [5]. Cells protect themselves against oxidants by numerous mechanisms. The most important $\mathrm{H}_{2} \mathrm{O}_{2}$-scavenging enzymes and related proteins with antioxidant capability include catalase, glutathione peroxidases, glutathione reductases and enzymes associated with the synthesis of reduced glutathione (GSH) such as $\gamma$-glutamyl cysteine synthase [4]. Superoxide dismutases (SODs) are metalloenzymes that catalyze the dismutation of superoxide anions into molecular oxygen and hydrogen peroxide; 
they represent a major cellular defense mechanism involved in the neutralization of ROS in both prokaryotic and eukaryotic organisms. They have been found in nearly all organisms and play a major role in the defense against oxidative stress [6]. The increased SOD activity decreases superoxide content in the cells and thus reduces the ROS-mediated stimulation of cell growth. It may be hypothesized that MnSOD would decrease cancer cell proliferation indirectly through reduction of ROS, unlike conventional tumor suppressors, which regulate cell growth and decrease expression of cancer cells [7].

Polysaccharides with a scavenging effect on the hydroxyl radicals have one or more alcohol or phenol hydroxyl groups. The scavenging ability is related to the number of active hydroxyl groups in the molecule [8]. And with the decrease of molecular weights, the antioxidant activity will be enhanced due to the partly destroying of intermolecular and intramolecular hydrogen bonds [9]. Chitosan is a natural polysaccharide obtained from crustacean shells and is composed of 2-amino-2deoxy- $\beta$-d-glucan combined with glycosidic linkages. The primary amine groups render special properties that make chitosan very useful in pharmaceutical applications. The non-toxicity, biodegradability and biocompatibility make chitosan suitable for various biomedical applications such as drug delivery [10].

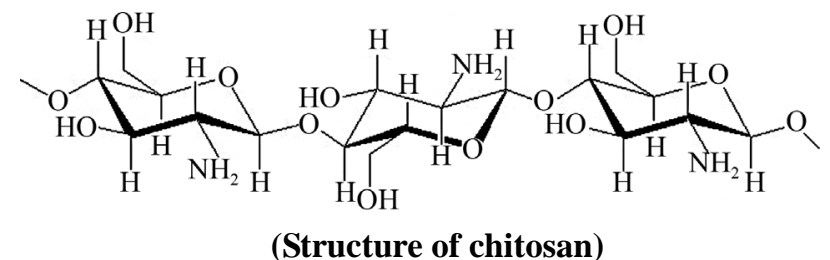

The properties of chitosan, such as its poor solubility in water or in organic solvents, can limit its utilization for a specific application. An elegant way to improve or to impart new properties to chitosan is the chemical modification of the chain, generally by grafting of functional groups, without modification of the initial skeleton in order to conserve the original properties. The functionalization is carried out on the primary amine group, generally by quaternization, or on the hydroxyl group [11]. Due to the presence of amine $\left(-\mathrm{NH}_{2}\right)$ groups and hydroxyl $(-\mathrm{OH})$ groups, chitosan can be modified to generate various novel derivatives with varying solubility patterns. Among the various derivatives $\mathrm{O}, \mathrm{N}$ carboxymethyl chitosan has been found to elicit broad range of biological activities and proved to be useful in pharmaceutical applications [12]. In addition, antitumor activity of chitosan has been claimed by inhibition of the growth of tumor cells mainly due to an immune stimulation effect by enhancement of antibody response [13]. Treatment with carboxymethyl chitosan suppressed the formation of intracellular reactive oxygen species (ROS), protein oxidation and lipid peroxidation in a concentra- tion-dependent manner. In addition, a protective effect against oxidative damage of the purified genomic DNA was observed in the presence of CM-chitosan [14].

An amphiphilic stearic acid-grafted chitosan oligosaccharide (CSO-SA) was synthesized, and utilized to fabricate micelles for the delivery of antitumor drug. Due to the spatial structure with multi-hydrophobic core, the CSO-SA micelles could rapidly be internalized into tumor cells, and could show different cellular uptake abilities in different tumor cell lines [15].

Vascular endothelial growth factor (VEGF) is a potent regulator of angiogenesis [16]. Angiogenesis is essential for conditions requiring an increase in blood and oxygen supply, including reproduction, physiological repair (e.g., wound and tissue healing and exercise) [17]. In addition to its relevance in physiological conditions, angiogenesis has a prominent role in diseases such as preeclampsia, ischemic heart disease, and cancer. Neovascularization allows for cancer development, tumor growth, and metastasis whereby the tumor elicits the formation of capillaries to obtain its own blood supply [18]. Transforming growth factor beta (TGF- $\beta$ ) is a multifunctional cytokine involved in the regulation of cell proliferation, differentiation and survival/or apoptosis of many cells. TGF- $\beta$ is implicated in the pathogenesis of human diseases, including tissue fibrosis and carcinogenesis. TGF- $\beta$ may contribute to tumour pathogenesis by direct support of tumour growth and influence on local microenvironment, resulting in immunosuppression, induction of angiogenesis, and modification of the extracellular matrix [19].

Experimental tumors have great importance in modeling, and Ehrlich ascites carcinoma (EAC) is one of the commonest tumors. EAC is referred to as an undifferentiated carcinoma and is originally hyper diploid, has high transplantable capability, no-regression, rapid proliferation, shorter life span, 100\% malignancy and also does not have tumor-specific transplantation antigen (TSTA). The ideal drug being ineffective or minimally effective for normal cells had been focused on, and at this point, the usage of natural sources as an alternative cancer therapy is thought to have a great value for cancer control [20]. Therefore, the goal of the present work was to prepare stearic acid-grafted carboxymethyl chitosan and investigate its antitumor activity, via downregulation of transforming growth factor-B (TGF-B) and vascular endothelial growth factor (VEGF) in EAC-bearing mice.

\section{MATERIALS \& METHODS}

\subsection{Preparation of Carboxymethyl Chitosan}

Carboxymethyl chitosan was prepared by the method of Liu et al. [21]. $10 \mathrm{~g}$ of chitosan $\left(8.4 \times 10^{4}\right.$, the degree of deacetylation $85 \%$ ) purchased from Sigma Aldrich, 
USA, $13.5 \mathrm{~g}$ sodium hydroxide and $100 \mathrm{ml}$ of isopropanol mixed in a $500 \mathrm{ml}$ flask at $50^{\circ} \mathrm{C}$ for $1 \mathrm{~h}$ and $15 \mathrm{~g}$ of monochloroacetic acid dissolved in $20 \mathrm{ml}$ isopropanol were added into the reaction mixture dropwise for 30 $\min$. The reaction was preceded for $4 \mathrm{~h}$ at the same temperature, and then stopped by adding $200 \mathrm{ml} 70 \%$ ethyl alcohol. The solid was filtered, rinsed with $70 \%-90 \%$ ethyl alcohol, and dried under vacuum at room temperature. The produced $\mathrm{Na}$ salt of CM-chitosan $(1 \mathrm{~g})$ was suspended in $100 \mathrm{ml} 80 \%$ ethyl alcohol then $10 \mathrm{ml}, 37 \%$ hydrochloric acid was added and the mixture was stirred for $30 \mathrm{~min}$. The produced solid was filtered, rinsed with $70 \%-90 \%$ ethyl alcohol and dried under vacuum. The produced H-form was charachterized by FT/IR-430 Fourier Transform Infrared Spectrometer.

\subsection{Preparation of Stearic Acid-Grafted Carboxymethyl Chitosan}

Stearic acid grafted carboxymethyl chitosan was prepared by the method of $\mathrm{Hu}$ et al. [22]. The prepared carboxymethyl chitosan $(1.0 \mathrm{~g})$ was dissolved in $50 \mathrm{ml}$ of distilled water. Stearic acid $(0.85 \mathrm{~g})$ and ethyl dimethylaminopropyl carbodiimide (EDC) $(10 \mathrm{~mol} / \mathrm{mol}$ of stearic acid) were dissolved in $30 \mathrm{ml}$ of ethanol. Carboxymethyl chitosan solution was heated at $70^{\circ} \mathrm{C}$ under vigorous stirring accompanied by drop wise addition of stearic acid solution. The reaction was continued for $8 \mathrm{~h}$ after which, the reaction mixture was extensively dialyzed against distilled water for $48 \mathrm{~h}$. The obtained product was lyophilized, further washed with ethanol, and separated by centrifugation $3000 \mathrm{rpm}$. The resulted product was dried in a vacuum oven at $45^{\circ} \mathrm{C}$ and charachterized by FT/IR430 Fourier Transform Infrared Spectrometer.

\subsection{In Vitro Cytotoxicity of SA-CMC against EAC Cells}

Viable EAC cells were calculated using trypan blue stain by the method of Maclimans et al. [23]. After treatment with SA-CMC $0.2 \mathrm{ml}$ of $0.32 \%$ trypan blue was mixed with $0.2 \mathrm{ml}$ of EAC cells and incubated for 10 minutes at $37^{\circ} \mathrm{C}$. The number of viable tumor cells, unstained cells, was counted within 5 minutes after incubation using a homocytometer.

Cells $/ \mathrm{ml}=$ average count per square $\times$ dilution factor $\times 104$

Total cells $=$ cells $/ \mathrm{ml} \times$ total original volume of cell suspension from which sample was taken.

$\%$ of viable cells $=($ no of unstained cells/total cells $)$ $\times 100$

\subsection{Animals and Tumor Cell Line}

All experiments were performed on adult female Swiss albino mice purchased from Theodore Bilharz Research Institute, Giza, Egypt, with an average body weight of 25 to $30 \mathrm{~g}$. Mice were housed in steel mesh cages (10 mice/ cage) and maintained for two weeks acclimatization period on commercial standard diet and tap water. The mice were randomly divided into 6 groups, 15 animals each, according to the following scheme:

Group I: Normal mice saline-treated group (control): Each moue was intraperitoneally injected with daily $0.2 \mathrm{ml}$ of the physiological saline solution for 10 days.

Group II: Normal mice treated with diluted acetic acid: Each moue was intraperitoneally injected with daily $0.2 \mathrm{ml}$ of $1 \%$ acetic acid solution for 10 days.

Group III: Normal mice treated with SA-CMC: Each mouse was intraperitoneally injected with $40 \mathrm{mg} /$ $\mathrm{kg} /$ day of the SA-CMC for 10 days. $40 \mathrm{mg} / \mathrm{kg} /$ day were chosen since LD50 was estimated in our laboratory to be $400 \mathrm{mg} / \mathrm{kg} /$ day (unpublished data).

GroupVI: EAC-bearing mice treated with saline: Each mouse was intraperitoneally injected once with $1 \times$ 106 tumor cells. After 24 hours of cells inoculation, the mouse was intraperitoneally injected with daily $0.2 \mathrm{ml}$ of the physiological saline solution for 10 days.

GroupVI: EAC-bearing mice treated with diluted acetic acid: Each mouse was intraperitoneally injected once with $1 \times 106$ tumor cells. After 24 hours of cells inoculation, the mouse was intraperitoneally injected with daily $0.2 \mathrm{ml} 1 \%$ acetic acid solution for 10 days.

GroupVI: EAC-bearing mice treated with SA-CMC: Each mouse was intraperitoneally injected once with $1 \times$ 106 tumor cells. After 24 hours of cells inoculation, the mouse was intraperitoneally injected with $0.2 \mathrm{ml}$ solution containing $40 \mathrm{mg} / \mathrm{kg} /$ day of SA-CMC for 10 days.

\subsection{Determination of Median Survival Time (MST) and Increase in Life Span (ILS\%) of Mice}

The mortality was monitored by recording percentage increase in life span and median survival time [24] using the following formula:

Median Survival Time $($ MST $)=($ Day of first death + day of last death) $/ 2$

Increase in life span $($ ILS\% $)=($ MST (treated $) /$ MST (Tumor) $) \times 100$

\subsection{Samples}

Three weeks after the last treatment, all animals were sacrificed; ascetic fluid was individually withdrawn from each mouse of groups 4, 5 and 6 and measured. Liver samples were quickly dissected, rinsed with isotonic saline and dried. $0.25 \mathrm{~g}$ of these tissues was homogenized in ice cooled saline and diluted to yield a $5 \%(\mathrm{w} / \mathrm{v})$. The supernatant was used for biochemical analysis. Blood 
samples were collected by tail vein cutting and their sera were used. All experimental procedures were approved by the committee for animal experiments of Mansoura University.

\subsection{Biochemical Tests}

Total counts of WBCs and platelets were determined according to the technique described by Dacie and Lewis [25]. For this assay, an advanced Bright-Line Homocytometer was used (Bosch and Lomb USA). According to the method of Schneider et al. [26], nucleic acids were extracted from liver homogenate. DNA content was determined colorimetrically in the extract using diphenylamine procedure described by Dische and Schwarz [27] and RNA content was measured by the orcinol procedure described by Mejbaum et al. [28]. The method of Littelfield et al. [29] was used for the extraction of lipids from liver tissues. Total lipids in liver tissues were determined by the method of Knight et al. [30]. Serum alanine transaminase (ALT) was colorimetrically determined by the method of Reitman and Frankel [31]. Serum albumin concentration was determined by the method of Dumas et al. [32]. Erythrocyte reduced glutathione (GSH) content was determined by the method of Beutler et al. [33]. Malondialdehyde (MDA) level was determined in the blood by the method of Stocks and Dormandy [34]. Superoxide dismutase (SOD) activity in serum was assayed by the method of Nishikimi et al. [35]. Blood hemoglobin $(\mathrm{Hb})$ concentration was colourimetrically determined according to the method of Drakin and Austin [36]. Serum alkaline phosphatase (ALK-P) activity was determined by the method described by El-Aaser and ElMerzabani [37]. Serum gamma-glutamyl transferase $(\gamma$ GT) activity was determined by the method of Szasz et al. [38]. Nitric oxide (NO) activity was estimated in serum by the method of Berkels et al. [39] using a commercially available assay kit (Egyptian American Company for Laboratory Services, Egypt). TGF- $\beta$ was assayed using a commercially available assay ELISA kit (Sigma Aldrich, USA). VEGF was also assayed using a commercially available assay ELISA kit (Sigma Aldrich, USA) following manufacturer's guidelines.

\subsection{Statistical Analysis}

The statistical analyses of the results were carried out using Instate software computer program, version 2.03 (Graph pad, USA) and IBM PC compatible computer. The difference is significant, and highly significant, when the corresponding value of probability (P) was $\leq 0.05$ and $\leq 0.001$, respectively. Correlation coefficient ( $\mathrm{r}$ ) was used for measuring the relationship between two variables. The correlation is considered weak at $\mathrm{r}=0.50$, moderate at $\mathrm{r}$ $=0.50-0.75$ and strong at $\mathrm{r}=0.80-1.00$.

\section{RESULTS}

The IR spectra of chitosan, carboxymethyl chitosan and stearic acid grafted carboxymethyl chitosan prepared under the optimal conditions are shown in Figure 1. Figure 1(a) shows that the main characteristic peaks of chitosan are at $3455 \mathrm{~cm}^{-1}$ (O-H stretch), $2879 \mathrm{~cm}(\mathrm{~N}-\mathrm{H}$ bend), $1327 \mathrm{~cm}^{-1}$ (C-N stretch), $1155 \mathrm{~cm}^{-1}$ (bridge $\mathrm{O}$ stretch), and $1092 \mathrm{~cm}^{-1}$ (C-O stretch). Figure 1(b) shows the main characteristic peaks of carboxymethyl chitosan and the intrinsic peaks of carboxyl group is at $1741 \mathrm{~cm}^{-1}$. The bands at $1599 \mathrm{~cm}^{-1}$ and $1401 \mathrm{~cm}^{-1}$ correspond to the carboxyl group (which overlaps with $\mathrm{N}-\mathrm{H}$ bend) and carboxymethyl group, respectively. Compared with the peaks of chitosan, the peaks of carboxymethyl chitosan at $1599 \mathrm{~cm}^{-1}$ and $1324 \mathrm{~cm}^{-1}$ increase, thus indicating that carboxymethylation has occurred on both the amino and hydroxyl groups of chitosan. Figure 1(c): The spectra of SA-CMC exhibited many alterations: the absorption at $3000-3600 \mathrm{~cm}^{-1}\left(\mathrm{OH}, \mathrm{NH}_{2}\right)$ decreased, and the band at $1570 \mathrm{~cm}^{-1}(\delta \mathrm{N}-\mathrm{H}$ of amide) decreased, whereas prominent bands at $1655 \mathrm{~cm}^{-1}(\gamma \mathrm{C}=\mathrm{O})$ and $1555 \mathrm{~cm}^{-1}(\delta \mathrm{N}-\mathrm{H}$ of amide II) were observed. The peaks at $2924 \mathrm{~cm}^{-1}(\gamma$ $\left.\mathrm{CH}_{2}\right), 2854 \mathrm{~cm}^{-1}(\gamma \mathrm{CH})$, and $\left.1464 \mathrm{~cm}^{-1}\right)$ confirm that chitosan is substituted. The in vitro study revealed that (SA-CMC) has SOD-like activity and its activity increased with increasing the concentration and reached $89 \%$ at $5 \mathrm{mg} / \mathrm{ml}$ (Table 1 ). The cytotoxicity of SA-CMC using different concentrations on viable EAC cells was tested. The percentage of dead cells increased with increasing the concentration of SA-CMC and reached 78\% at $5 \mathrm{mg} / \mathrm{ml}$ (Table2).

In EAC-bearing mice saline treated group, the median Survival time (MST) is $12.25 \pm 2.5$ days (Figure 2(a)), whereas in EAC-bearing mice treated with SA-CMC the median survival time is $21.5 \pm 4.43$ (Figure 2(b)) and there is an increase in life spans (ILS\%) reaching $175.5 \%$. Figure 3 shows difference between EAC-bearing mice saline treated (a) and EAC-bearing mice treated with

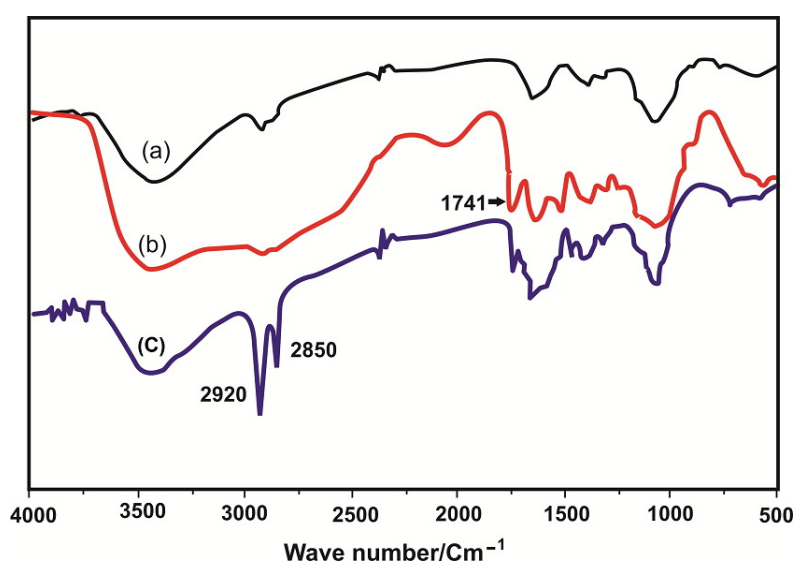

Figure 1. FT-IR spectra of (a) chitosan; (b) carboxymethyl chitosan; (c) stearic acid-Grafted carboxymethyl chitosan. 
Table 1. In vitro SOD like activity of stearic acid-grafted carboxymethyl chitosan.

\begin{tabular}{cc}
\hline Conc (mg/ml solvent) & \% Inhibition \\
\hline $2 \mathrm{mg} / \mathrm{ml}$ & $42 \%$ \\
$3 \mathrm{mg} / \mathrm{ml}$ & $63 \%$ \\
$4 \mathrm{mg} / \mathrm{ml}$ & $71 \%$ \\
$5 \mathrm{mg} / \mathrm{ml}$ & $89 \%$ \\
\hline
\end{tabular}

Table 2. In vitro cytotoxicity of stearic acid-grafted carboxymethyl chitosan against EAC-cells.

\begin{tabular}{ccc}
\hline Conc (g/ml solvent) & (Dead cells) $\%$ & (Survived cells) $\%$ \\
\hline Control & $23 \%$ & $77 \%$ \\
$2 \mathrm{mg} / \mathrm{ml}$ & $32 \%$ & $68 \%$ \\
$3 \mathrm{mg} / \mathrm{ml}$ & $63 \%$ & $37 \%$ \\
$4 \mathrm{mg} / \mathrm{ml}$ & $71 \%$ & $29 \%$ \\
$5 \mathrm{mg} / \mathrm{ml}$ & $78 \%$ & $22 \%$ \\
\hline
\end{tabular}

\section{SA-CMC (b).}

As shown in Table 3, there are highly significant decreases in levels of $\mathrm{Hb}$, counts of RBCs and Platelets; and an increase in WBCs in groups IV and V compared to group I. However, the values of these parameters return to the normal values in treated group VI.

The levels of MDA and NO are highly increased in mice of groups IV and V compared to the control group. However, erythrocytes GSH content in mice of groups IV and V is highly significantly decreased and SOD activity in serum of group $\mathrm{V}$ is significantly decreased compared to the control group, while SOD activity in serum of group IV is significantly increased compared to the control group (Table 4). In liver tissues of groups IV and $\mathrm{V}$, the total lipids are highly significantly decreased, while DNA and RNA contents are highly significantly increased compared to those of controls. However, the values of total lipid, RNA and DNA remain as in the normal in the tumorized group treated with SA-CMC. In addition, no significant changes are observed in these values in groups II and III compared to the control group (Table 5).

The total ascetic fluid volume and serum levels of VEGF and TGF- $\beta$ in mice of groups IV and V are highly significantly elevated compared to the corresponding levels of the control group while serum levels of VEGF and TGF- $\beta$ in tumorized mice treated with SA-CMC remain within normal values and the total ascetic volume of this group is minimum $(1.3 \mathrm{ml}$ compared to $8.8 \mathrm{ml}$ in the tumorized untreated group) (Table 6). Serum albumin of mice of groups IV and V is highly significantly decreased compared to that of the control group. However, the activities of ALT, ALK-P and GGT in serum of mice of groups IV and V are highly significantly increased compared to those of group I. On the other hand, no significant differences are observed in these values between groups I, II, III and VI (Table 7). Figure 3 Shows the

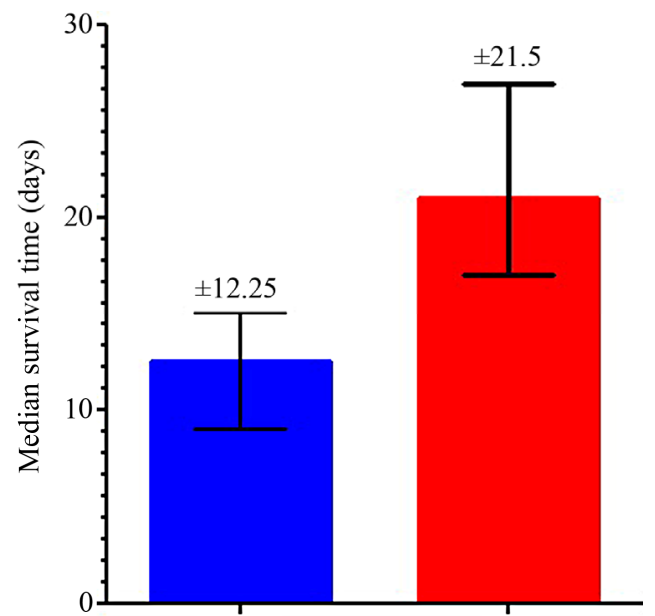

(a)

(b)

Figure 2. Median survival time of EAC-saline treated group (a) and EAC-bearing mice treated with SA-CMC (b).

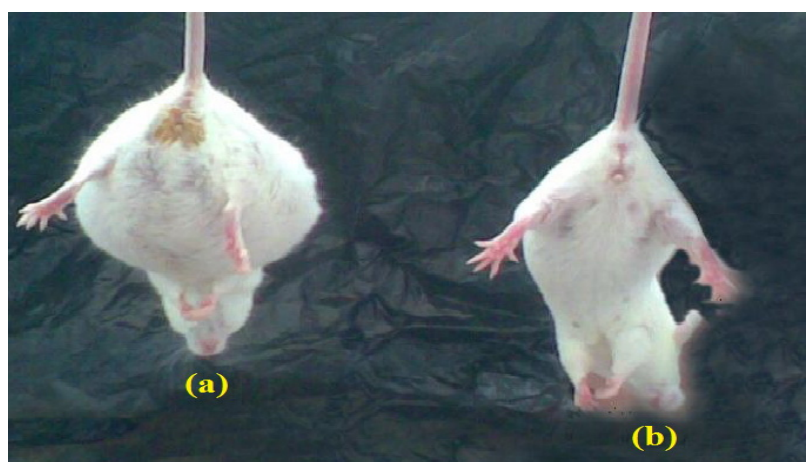

Figure 3. Abdominal view of EAC- bearing mice -saline treated (a) versus EAC-bearing mice treated with SA-CMC (b).

significance difference between EAC-bearing mice saline treated (a) and EAC-bearing mice treated with SACMC (b). Table 8 shows different correlations between the different parameters in all groups.

\section{DISCUSSION}

The mechanisms that mediate the biological activity of polysaccharides still are not clearly understood. Polysaccharides from natural resources usually do not attack cancer cells directly, but produce their antitumor effects by activating different immune responses in the host. The antitumor action of polysaccharides requires an intact T-cell component and their activity is mediated through a thymus-dependent immune mechanism [40]. Ehrlich tumor produce overload free radicals and polysaccharides can scavenge these radicals. The scavenging ability is related to the number of active hydroxyl groups in the molecule [8]. Park et al. [41] reported that chitosan has shown a significant scavenging capacity against different radical species; the results being comparable to those 
Table 3. Hb concentration and total counts of RBCs, WBCs and platelets in mice of groups (I - VI).

\begin{tabular}{ccccc}
\hline Parameters groups & $\mathrm{HB}$ g/dL & RBCs cells $/ \mathrm{mm}^{3} \times 10^{6}$ & WBCs count $\times 10^{3} / \mu 1$ & Platelets count $\times 10^{3} / \mu 1$ \\
\hline G I & $11.70 \pm 1.52$ & $4.3 \pm 0.55$ & $8.0 \pm 0.91$ & $301 \pm 44.0$ \\
G II & $11.30 \pm 1.76$ & $3.6 \pm 0.56$ & $8.6 \pm 0.84$ & $245 \pm 51.0$ \\
G III & $10.88 \pm 1.78$ & $3.9 \pm 0.68$ & $9.9 \pm 2.70$ & $254 \pm 66.0$ \\
G IV & $9.55 \pm 1.87^{*}$ & $3.2 \pm 0.85^{*}$ & $15.6 \pm 0.81^{* *}$ & $214 \pm 53.0^{*}$ \\
G V & $9.50 \pm 1.20^{* *}$ & $3.4 \pm 0.43^{*}$ & $15.7 \pm 2.01^{* *}$ & $205 \pm 68.0^{*}$ \\
G VI & $11.21 \pm 1.12^{\$}$ & $4.4 \pm 0.44^{\$}$ & $9.6 \pm 1.45^{\text {s\$ }}$ & $301 \pm 56.0^{\$}$ \\
\hline
\end{tabular}

Number of cases $=9$; ${ }^{*}$ Significant $(\mathrm{P}<0.05) ;{ }^{* *}$ Highly significant $(\mathrm{P}<0.001)$ compared to group I; ${ }^{\$}$ Significant $(\mathrm{P}<0.05) ;{ }^{\$ \$}$ Highly significant $(\mathrm{P}<0.001)$ compared to group IV.

Table 4. SOD activity and blood levels of GSH, nitric oxide, and MDA in mice of groups (I - VI).

\begin{tabular}{ccccc}
\hline Parameters group & SOD inhibition $\%$ & GSH $(\mathrm{mmol} / \mathrm{ml}$ cells $)$ & NO $(\mathrm{M} \mu)$ & MDA mol/ml packed cell $\times 10^{-6}$ \\
\hline G I & $40.10 \pm 10.04$ & $2.75 \pm 0.64$ & $43.30 \pm 5.10$ & $6.54 \pm 1.04$ \\
G II & $41.68 \pm 10.07$ & $2.18 \pm 1.09$ & $39.30 \pm 7.70$ & $7.28 \pm 0.93$ \\
G III & $44.31 \pm 10.46$ & $2.27 \pm 0.71$ & $41.50 \pm 6.35$ & $6.66 \pm 1.06$ \\
G IV & $49.90 \pm 4.70^{*}$ & $1.27 \pm 0.76^{* *}$ & $90.80 \pm 4.83^{* *}$ & $11.65 \pm 2.92^{* *}$ \\
G V & $30.00 \pm 7.00^{* \$}$ & $1.09 \pm 0.61^{* *}$ & $88.80 \pm 6.34^{* *}$ & $10.57 \pm 1.96^{* *}$ \\
G VI & $74.91 \pm 12.70^{* * \$}$ & $2.21 \pm 0.70^{\$}$ & $53.30 \pm 7.80^{* \$}$ & $7.31 \pm 2.11^{\$}$ \\
\hline
\end{tabular}

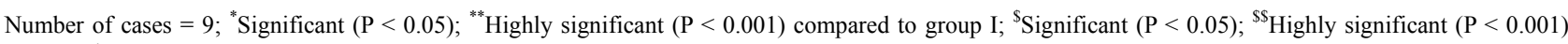
compared to group IV.

Table 5. Levels of total lipids, DNA and RNA in liver tissues of mice of groups (I - VI).

\begin{tabular}{|c|c|c|c|}
\hline Parameters group & Total lipids ( $\mu \mathrm{g} / \mathrm{gm}$ tissue) & DNA ( $\mu \mathrm{g} / \mathrm{gm}$ tissue $)$ & $\mathrm{RNA}(\mu \mathrm{g} / \mathrm{gm}$ tissue $)$ \\
\hline G I & $493.0 \pm 138.2$ & $87.6 \pm 6.8$ & $119.1 \pm 6.9$ \\
\hline G II & $465.1 \pm 68.9$ & $89.5 \pm 5.3$ & $120.3 \pm 6.4$ \\
\hline G III & $469.6 \pm 102.2$ & $90.6 \pm 7.2$ & $124.5 \pm 4.7$ \\
\hline G IV & $241.3 \pm 51.1^{* *}$ & $136.0 \pm 11.8^{* *}$ & $167.6 \pm 13.4^{* *}$ \\
\hline G V & $198.4 \pm 47.2^{* *}$ & $142.7 \pm 10.4^{* *}$ & $175.5 \pm 9.0^{* *}$ \\
\hline G VI & $426.2 \pm 95.0^{\$ \$}$ & $96.9 \pm 10.8^{* \$ \$}$ & $125.1 \pm 6.4^{\$ S}$ \\
\hline
\end{tabular}

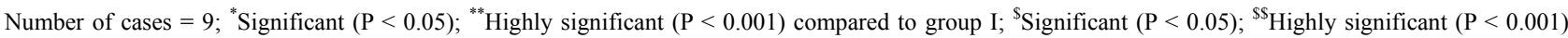
compared to group IV.

Table 6. Total ascetic fluid volume and serum levels of VEGF and TGF- $\beta$ in mice of groups (I - VI).

\begin{tabular}{cccc}
\hline Parameters groups & Ascitic volume ml & VEGF Pg/ml & TGF- $\beta$ Pg/ml \\
\hline G I & - & $122.2 \pm 24.7$ & $102.6 \pm 12.4$ \\
G II & - & $126.6 \pm 22.3$ & $110.6 \pm 14.9$ \\
G III & - & $126.1 \pm 21.8$ & $114.5 \pm 11.6$ \\
G IV & $8.8 \pm 1.38^{* *}$ & $634.0 \pm 52.0^{* *}$ & $529.8 \pm 39.7^{* *}$ \\
G V & $8.0 \pm 1.10^{* *}$ & $659.6 \pm 55.1^{* *}$ & $534.5 \pm 34.9^{* *}$ \\
G VI & $1.3 \pm 1.43^{* \mathrm{ss}}$ & $149.3 \pm 11.4^{* \$ \$}$ & $115.3 \pm 12.7^{\$ \$}$ \\
\hline
\end{tabular}

Number of cases $=8 ;$; Significant $(\mathrm{P}<0.05) ;{ }^{* *}$ Highly significant $(\mathrm{P}<0.001)$ compared to group I; ${ }^{\$}$ Significant $(\mathrm{P}<0.05) ;{ }^{\$ \$}$ Highly significant $(\mathrm{P}<0.001)$ compared to group IV. 
Table 7. Serum albumin level and Serum activities of ALT, ALK-P and GGT in mice of groups (I - VI).

\begin{tabular}{|c|c|c|c|c|}
\hline Parameters groups & Albumin g/dL & ALT IU/L & ALK-P IU/L & GGT IU/L \\
\hline G I & $2.74 \pm 0.27$ & $27.8 \pm 5.2$ & $78.4 \pm 9.5$ & $29.8 \pm 9.9$ \\
\hline G II & $2.64 \pm 0.25$ & $29.8 \pm 6.9$ & $79.7 \pm 8.5$ & $30.7 \pm 8.6$ \\
\hline G III & $2.75 \pm 0.31$ & $32.4 \pm 6.8$ & $80.0 \pm 8.9$ & $30.8 \pm 10.4$ \\
\hline G IV & $1.80 \pm 0.37^{* *}$ & $52.2 \pm 6.4^{* *}$ & $121.6 \pm 13.1^{* *}$ & $110.6 \pm 14.0^{* *}$ \\
\hline G V & $1.73 \pm 0.38^{* *}$ & $51.5 \pm 7.1^{* *}$ & $120.8 \pm 7.6^{* *}$ & $117.8 \pm 15.4^{* *}$ \\
\hline G VI & $2.34 \pm 0.37^{* \$ \$}$ & $33.5 \pm 5.9^{* \$ S}$ & $87.5 \pm 12.2^{\$ \$}$ & $36.6 \pm 6.3^{\$ \$}$ \\
\hline
\end{tabular}

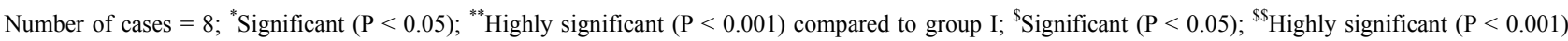
compared to group IV.

Table 8. Correlations between the different parameters of mice of groups (I - VI).

\begin{tabular}{|c|c|c|c|c|c|c|c|c|c|c|}
\hline & & ALT & ALK-P & GGT & $\begin{array}{l}\text { Ascitic } \\
\text { Volume }\end{array}$ & DNA & RNA & MDA & VEGF & TGF- $\beta$ \\
\hline ALBUMIN & $\begin{array}{l}\mathrm{R} \\
\mathrm{P}\end{array}$ & $\begin{array}{c}-0.74 \\
<0.0001\end{array}$ & $\begin{array}{c}-0.62 \\
<0.0001\end{array}$ & $\begin{array}{c}-0.77 \\
<0.0001\end{array}$ & $\begin{array}{c}-0.81 \\
<0.0001\end{array}$ & $\begin{array}{c}-0.76 \\
<0.0001\end{array}$ & $\begin{array}{c}-0.72 \\
<0.0001\end{array}$ & $\begin{array}{c}-0.52 \\
0.0021\end{array}$ & $\begin{array}{c}-0.75 \\
<0.0001\end{array}$ & $\begin{array}{c}-0.74 \\
<0.0001\end{array}$ \\
\hline SOD & $\begin{array}{l}R \\
P\end{array}$ & $\begin{array}{c}0.17 \\
>0.05\end{array}$ & $\begin{array}{c}0.21 \\
>0.05\end{array}$ & $\begin{array}{l}0.081 \\
>0.05\end{array}$ & $\begin{array}{c}0.13 \\
>0.05\end{array}$ & $\begin{array}{c}0.12 \\
>0.05\end{array}$ & $\begin{array}{l}0.047 \\
>0.05\end{array}$ & $\begin{array}{l}0.095 \\
>0.05\end{array}$ & $\begin{array}{c}0.13 \\
>0.05\end{array}$ & $\begin{array}{l}0.103 \\
>0.05\end{array}$ \\
\hline GSH & $\begin{array}{l}R \\
P\end{array}$ & $\begin{array}{c}-0.52 \\
0.0003\end{array}$ & $\begin{array}{c}-0.67 \\
<0.0001\end{array}$ & $\begin{array}{c}-0.60 \\
<0.0001\end{array}$ & $\begin{array}{c}-0.59 \\
<0.0001\end{array}$ & $\begin{array}{c}-0.54 \\
0.0001\end{array}$ & $\begin{array}{c}-0.58 \\
<0.0001\end{array}$ & $\begin{array}{l}-0.35 \\
0.0440\end{array}$ & $\begin{array}{c}-0.58 \\
<0.0001\end{array}$ & $\begin{array}{c}-0.55 \\
0.0001\end{array}$ \\
\hline T. LIPIDS & $\begin{array}{l}\mathrm{R} \\
\mathrm{P}\end{array}$ & $\begin{array}{c}-0.66 \\
<0.0001\end{array}$ & $\begin{array}{c}-0.63 \\
<0.0001\end{array}$ & $\begin{array}{c}-0.83 \\
<0.0001\end{array}$ & $\begin{array}{c}-0.78 \\
<0.0001\end{array}$ & $\begin{array}{c}-0.72 \\
<0.0001\end{array}$ & $\begin{array}{c}-0.79 \\
<0.0001\end{array}$ & $\begin{array}{c}-0.46 \\
0.0073\end{array}$ & $\begin{array}{c}-0.77 \\
<0.0001\end{array}$ & $\begin{array}{c}-0.77 \\
<0.0001\end{array}$ \\
\hline HB & $\begin{array}{l}\mathrm{R} \\
\mathrm{P}\end{array}$ & $\begin{array}{c}-0.51 \\
0.0002\end{array}$ & $\begin{array}{l}-0.43 \\
0.0020\end{array}$ & $\begin{array}{l}-0.52 \\
0.0001\end{array}$ & $\begin{array}{l}-0.47 \\
0.0007\end{array}$ & $\begin{array}{l}-0.46 \\
0.0009\end{array}$ & $\begin{array}{c}-0.54 \\
<0.0001\end{array}$ & $\begin{array}{l}-0.27 \\
>0.05\end{array}$ & $\begin{array}{l}-0.51 \\
0.0004\end{array}$ & $\begin{array}{l}-0.47 \\
0.0010\end{array}$ \\
\hline RBCs & $\begin{array}{l}\mathrm{R} \\
\mathrm{P}\end{array}$ & $\begin{array}{l}-0.45 \\
0.0121\end{array}$ & $\begin{array}{l}-0.47 \\
0.0085\end{array}$ & $\begin{array}{l}-0.50 \\
0.0045\end{array}$ & $\begin{array}{c}-0.44 \\
0.0148\end{array}$ & $\begin{array}{c}-0.38 \\
0.0352\end{array}$ & $\begin{array}{c}-0.47 \\
0.0076\end{array}$ & $\begin{array}{l}-0.25 \\
>0.05\end{array}$ & $\begin{array}{l}-0.51 \\
0.0037\end{array}$ & $\begin{array}{c}-0.50 \\
0.0049\end{array}$ \\
\hline WBCs & $\begin{array}{l}R \\
P\end{array}$ & $\begin{array}{l}-0.65 \\
0.0001\end{array}$ & $\begin{array}{c}-0.62 \\
0.0003\end{array}$ & $\begin{array}{l}-0.66 \\
0.0001\end{array}$ & $\begin{array}{c}-0.69 \\
<0.0001\end{array}$ & $\begin{array}{c}-0.62 \\
0.0003\end{array}$ & $\begin{array}{l}-0.61 \\
0.0003\end{array}$ & $\begin{array}{l}-0.45 \\
0.0142\end{array}$ & $\begin{array}{c}-0.69 \\
<0.0001\end{array}$ & $\begin{array}{c}-0.60 \\
<0.0001\end{array}$ \\
\hline PLT & $\begin{array}{l}R \\
P\end{array}$ & $\begin{array}{l}-0.45 \\
0.0133\end{array}$ & $\begin{array}{l}-0.33 \\
>0.05\end{array}$ & $\begin{array}{l}-0.50 \\
0.0046\end{array}$ & $\begin{array}{l}-0.45 \\
0.0131\end{array}$ & $\begin{array}{l}-0.37 \\
0.0426\end{array}$ & $\begin{array}{l}-0.43 \\
0.0192\end{array}$ & $\begin{array}{l}-0.44 \\
0.0160\end{array}$ & $\begin{array}{c}-0.48 \\
0.0078\end{array}$ & $\begin{array}{l}-0.50 \\
0.0051\end{array}$ \\
\hline
\end{tabular}

(P) Probability; $(\mathrm{R})$ Correlation coefficient, difference is significant $(\mathrm{P} \leq 0.05)$, highly significant $(\mathrm{P} \leq 0.001)$, correlation is considered weak at $\mathrm{r}=0.50$, moderate at $\mathrm{r}=0.50-0.75$ and strong at $\mathrm{r}=0.80-1.00$.

obtained with commercial antioxidants. Similar to that, in the present study, the prepared SA-CMC showed high SOD-like activity (Table 1) and revealed a high damaging effect against EAC cells in vitro (Table 2).

Depending on the in vitro results, SA-CMC was used in the present study as antitumor agent in mice inoculated with EAC-cells. The hematological parameters of the untreated tumor-bearing mice were significantly changed from those of the normal group. Treating with SA-CMC raised life span to $175.5 \%$ more than EAC tumor bearing group (untreated group). There were decreases in the levels of $\mathrm{Hb}$, and counts of RBCs and platelets and an increase in WBCs in EAC-bearing mice (Table 3). This depletion in RBCs count or hemoglobin content in tumor bearing mice might be mainly due to either iron deficiency or hemolytic or myelopathic conditions [42]. Treatment of EAC-bearing mice with SA$\mathrm{CMC}$ brought back the hemoglobin content and $\mathrm{RBC}$, WBC and platelets counts more or less to the normal levels. Kalaiselvi et al. [43] used jasminum sambac flower against Dalton lymphoma ascites (DLA) and Mazumder et al. [44] used Cucurbita maxima against Herlich ascites carcinoma and both research groups reported similar observations. Glutathione, a potent inhibitor of neoplastic process present in high concentration in liver, plays an important role as an endogenous antioxidant and was known to have the key function in the protective process against lipid peroxidation [42]. In the present study, GSH was significantly decreased in EAC-bearing untreated groups, This decrease might be explained by the increase in the rate of transformation of GSH to oxidized glutathione (GSSG) as a result of GSH consumption to get rid of $\mathrm{H}_{2} \mathrm{O}_{2}$ [45]. In addition to the lack of amino acids composing GSH [46], MDA, the end product of lipid peroxidations, was reported to be higher in carcinomatous tissue than in non-disease organs and its level are associated with advanced clinical stages and tumor progression. The redox status of the tumorized untreated mice revealed high elevation in nitric oxide, and MDA levels and high reduction in SOD activity (Table 
4). The significant elevation in SOD in diluted acetic acid-treated tumor-bearing mice might be attributed to the host oxidative stress in response to the continual generation of free radicals by tumor cells [47]. The values of GSH, SOD, NO and MDA, were significantly restored to the normal levels in SA-CMC treated EACbearing mice (group VI, Table 4). These results may be explained by the free radical scavenging effect of SACMC. Many reports suggested that the scavenging mechanism of chitosan is based on that superoxide anion can react with active hydrogen atoms in chitosan to form a most stable macromolecular radical. Superoxide anion is a zwitterionic radical. It could react with free hydroxyl and amino groups in chitosan oligosaccharides. In other words, superoxide anion can be eliminated by this reaction. In addition, the presence of carboxymethyl chitosan can induce higher scavenging activities against intracellular ROS formation and significant inhibition of both protein oxidation and lipid peroxidation in a dose-dependent manner, Furthermore, DNA oxidation was inhibited in presence of CM-chitosan a finding confirming the results of Kong et al. [14]. The reducing power properties of carboxymethyl chitosan are generally associated with their action as antioxidant by breaking the free radicals chain by donating a hydrogen atom [48]. This result may be related to the fact that the introduction of electron-donating carboxymethyl group enhances the electron cloud density of active hydroxyl and amino groups, thus the electron-donating activity increases and the reducing power improves. The SOD-like activity of SA$\mathrm{CMC}$ would relief the stress of the free radicals and consequently MDA and NO are expected to be decreased, in addition to the decreased consumption of GSH. Recently, Mazumder et al. [44] reported that GSH and MDA were restored to near the normal values by treatment with methanol extract of Cucurbita maxima. The levels of total lipids were highly decreased in liver tissues of untreated EAC-bearing mice (groups IV and V). However, DNA and RNA contents were highly increased in liver tissues of the same groups (Table 5). The increase in DNA and RNA are attributed to the high replication of the tumor cells, this replication needs high energy; so tumor cell growth is usually consuming all energy sources including lipids and proteins. These explanations are confirmed by establishing a negative correlation between DNA and both total lipids and albumin (Table 8). Furthermore, the treatment of tumor-bearing mice with SA$\mathrm{CMC}$ exerted a marked effect in maintaining the values of total lipid, DNA and RNA within the normal levels causing retardation of tumor growth by inhibiting the tumor DNA synthesis [49]. The total ascetic volume and serum levels of VEGF and TGF- $\beta$ in mice of groups IV and $\mathrm{V}$ are highly elevated than the corresponding values of the control (Table 6). Ghosh et al. (2004) indicated that tumor volume and its growth rate increase with increasing angiogenesis and VEGF level of the host and the rate of VEGF secretion is positively correlated well with tumor volume. TGF- $\beta$ is a multifunctional cytokine involved in the regulation of cell proliferation, differentiation and survival/apoptosis of many cells. In addition, TGF- $\beta$ is implicated in the pathogenesis of human diseases, including tissue fibrosis and carcinogenesis. Also, TGF- $\beta$ may contribute to tumor pathogenesis by direct support of tumor growth and influence on local microenvironment, resulting in immunosuppression for all cells of the immune system, induction of angiogenesis, and modification of the extracellular matrix [50]. Moreover, TGF- $\beta 1,2$ stimulates production of VEGF which is a major stimulus in the promotion of angiogenesis, as well as plasminogen activator inhibitor (PAI-I) [51]. The downregulation effect of SA-CMC on TGF- $\beta$ and VEGF was appearent in the present results thtough the high inhibition of EAC-cell growth in the tumorized treated animals.

A mechanism is suggested for EAC-cell growth inhibition that involves immunostimulating effects of chitosan and its carboxymethyl derivatives via stimulation of cytolytic T-lymphocytes. This effect increases with smaller molecular sizes and it is suggested that they have immunostimulating effects that activate peritoneal macrophages and stimulate non-specific host resistance. However, higher $\mathrm{Mw}$ oligomers have also exhibited antitumor activity. The same mechanism has been suggested for their activity via increased production of lymphokines by activated lymphocytes [52]. Recently El-Far et al. [53] reported that, the cell cycle analysis revealed a $\mathrm{G} 2 / \mathrm{M}$ phase accumulation as well as a significant increase in sub-G1 phase cells after treatment with derivative of carboxymethylated chitosan (DCMC). This indicates an induction of apoptosis in EAC cells associated with a highly significant decrease in tumor volume. DCMC is a regulator of tumor cell growth and differentiation not only by causing G2/M cell cycle arrest but also by inducing their apoptotic death. DCMC has led to an aug mentation of the antioxidant defense system without affecting lipid peroxidation in EAC-bearing mice. The elevation in activities of ALT (marker of hepatocellular damage), ALK-P (marker of a pathological alteration in biliary flow) and GGT (cancer marker enzyme) reflect the tumor liver metastasis. These serum enzymes activeties were significantly restored to near normal levels after treatment with SA-CMC, and a reduction in tumor metastasis. Similar to that, reduction of all elevated enzymes $(\mathrm{P}<0.05)$ to near normal levels in animals treated with both Jasminum sambac and 5' fluorouracil [43].

\section{CONCLUSION}

From the above-mentioned observations, we can con- 
clude that, SA-CMC inhibites the tumor cell proliferation through downregulation of TGF- $\beta$ and VEGF.

\section{REFERENCES}

[1] Ishikawa, K., Takenaga, K., Akimoto, M., Koshikawa, N., Yamaguchi, A., Imanishi, H., Nakada, K., Honma, Y. and Hayashi, J. (2008) ROS generating mitochondrial DNA mutations can regulate tumor cell metastasis. Science, 320, 661-664.

[2] Klaunig, J.E. and Kamendulis, L.M.T. (2004) The role of oxidative stress in carcinogenesis. Annual Review of Pharmacology and Toxicology, 44, 239-267. doi:10.1146/annurev.pharmtox.44.101802.121851

[3] Tudek, B., Winczura, A., Janik, J., Siomek, A., Foksinski, M. and Olinski, R. (2010) Involvement of oxidatively damaged DNA and repair in cancer development and aging. American Journal of Translational Research, 2, 254284.

[4] Halliwell, B. and Gutteridge, J.M.C. (2006) Free radicals in biology and medicine. 4th Edition, Clarendon Press, Oxford.

[5] Abdal Dayem, A., Choi, H.-Y., Kim, J.-H. and Cho, S.-G. (2010) Role of oxidative stress in stem, cancer, and cancer stem cells. Cancers, 2, 859-884. doi:10.3390/cancers2020859

[6] Touati, D. (1997) Superoxide dismutases in bacteria and pathogen protests. In: Scandalios, J.G., Ed., Oxidative Stress and the Molecular Biology of Antioxidant Defenses, Cold Spring Harbor Laboratory, New York, 447-493.

[7] Pastore, A., Federici, G., Bertini, E. and Piemonte, F. (2003) Analysis of glutathione: Implication in redox and detoxification. Clinica Chimica Acta, 333, 19-39. doi:10.1016/S0009-8981(03)00200-6

[8] Guo, Z., Liu, H., Chen, X., Ji, X. and Li, P. (2006) Hydroxyl radicals scavenging activity of N-substituted chitosan and quaternized chitosan. Bioorganic \& Medicinal Chemistry Letters, 16, 6348-6350. doi:10.1016/j.bmcl.2006.09.009

[9] Xing, R., Liu, S., Guo, Z. Y., Yu, H.H., Zhong, Z.M., Ji, X. and Li, P.C. (2008) Relevance of molecular weight of chitosan-N-2-hydroxypropyl trimethyl ammonium chloride and their antioxidant activities. European Journal of Medicinal Chemistry, 43, 336-340. doi:10.1016/j.ejmech.2007.03.025

[10] Dev, A., Mohan, J. C., Sreeja, V., Tamura, H., Patzke, G., R. Hussain, F., Weyeneth, S., Nair, S.V. and Jayakumar, R. (2010) Novel carboxymethyl chitin nanoparticles for cancer drug delivery applications. Carbohydrate Polymers, 79, 1073-1079. doi:10.1016/i.carbpol.2009.10.038

[11] Riva, R., Ragelle, H., des Rieux, A., Duhem, N., Jérôme, C. and Préat, V. (2011) Chitosan and chitosan derivatives in drug delivery and tissue engineering. Advances in Polymer Science, 244, 19-44. doi:10.1007/12_2011_137

[12] Patale, R.L. and Patravale, V.B. (2011) N-carboxymethyl chitosan-zinc complex. A novel chitosan complex with enhanced antimicrobial activity. Carbohydrate Polymers, 85, 105-110. doi:10.1016/j.carbpol.2011.02.001
[13] Kim, S.K. and Rajapakse, N. (2005) Enzymatic production and biological activities of chitosan oligosaccharides (COS): A review. Carbohydrate Polymers, 62, 357-368. doi:10.1016/j.carbpol.2005.08.012

[14] Kong, C.-S., Kim, J.-A., Byulnim, A., Byun, H.-G. and Kim, S.-K. (2010) Carboxymethylations of chitosan and chitin inhibit MMP expression and ROS scavenging in human fibrosarcoma cells. Process Biochemistry, 45, 179186. doi:10.1016/i.procbio.2009.09.004

[15] Hu, F.Q., Wu, X.L., Du, Y.Z., You, J. and Yuan, H. (2008) Cellular uptake and cytotoxicity of shell crosslinked stearic acid-grafted chatoyant oligosaccharide micelles encapsulating doxorubicin. European Journal of Pharmaceutics and Biopharmaceutics, 69, 117-125. doi:10.1016/j.ejpb.2007.09.018

[16] Kut, C., Mac Gabhann, F. and Popel, A.S. (2007) A metaanalysis of VEGF distribution in cancer. British Journal of Cancer, 97, 978-985. doi:10.1038/sj.bjc.6603923

[17] Sung, H.K., Michael, I.P. and Nagy, A. (2010) Multifaceted role of vascular endothelial growth factor signaling in adult tissue physiology: An emerging concept with clinical implications. Current Opinion in Hematology, 17, 206-212.

[18] Carmeliet, P. and Jain, R.K. (2011) Molecular mechanisms and clinical applications of angiogenesis. Nature, 473, 298-307. doi:10.1038/nature10144

[19] Bozena, K., Aleksandra, W. and Malgorzata, D. (2005) TGF beta signalling and its role in tumour pathogenesis. Acta biochimica Polonica, 52, 329-337.

[20] Ozaslan, M., Karagoz, I.D., Kilic, I.H. and Guldur, M.H. (2011) Ehrlich ascites carcinoma. African Journal of Biotechnology, 10, 2375-2378.

[21] Liu, X.F., Guan, Y.L., Yang, D.Z., Li, Z. and Yao, K.D. (2001) Antibacterial action of chatoyant and carboxymethylated chatoyant. Journal of Applied Polymer Science, 1, 1324-1335.

[22] Hu, F.Q., Li, Y.H., Yuan, H. and Zeng, S. (2006) Novel self-aggregates of chitosan oligosaccharide grafted stearic acid: Preparation, characterization and protein association. Pharmazie, 61, 194-198.

[23] Maclimans, W.F., Davis, E.V., Glover, F.L. and Rake, G.W. (1957) The submerged culture of mammalian cells: The spinner culture. Journal of Immunology, 79, 428-433.

[24] Gupta, M., Mazumder, U.K., Kumar, R.S. and Kumar, T.S. (2004) Antitumor activity and antioxidant role of Bauhinia racemosa against Ehrlich ascites carcinoma in Swiss albino mice. Acta Pharmacologica Sinica, 25, 1070-1076.

[25] Dacie, S.J.V. and Lewis, S.M. (1984) Practical haematology. 6th Edition, Churchill Livingstone, Edinburgh, London, 22-27.

[26] Schneider, W.C. (1945) Phosphorous compounds in animal tissues I. Extraction and estimation of deoxypentose nucleic acid and of pentose nucleic acid. Journal of Biological Chemistry, 161, 293-303.

[27] Dische, Z. and Schwarz, K. (1937) Microchemical method for the determination of different pentoses in the presence of other pentoses and hexoses, Mikrochemica Acta, 2, 1319. doi: $10.1007 / \mathrm{BF} 01471868$ 
[28] Mejbaum, W. (1939) Estimation of small amounts of pentose especially in derivatives of adenylic acid. Journal of Physiological Chemistry, 258, 117-120.

[29] Littelfield, L.W., Keller, E.B., Gross, J. and Zamecnick, P.C. (1955) Studies on cytoplasmic ribonucleoprotein particles from liver of the rat. Journal of Biological Chemistry, 217, 111-117.

[30] Knight, J.A., Anderson, S. and Rawle, J.M. (1972) Chemical basis of the sulfophosphovanillin reaction of estimateing total serum lipids. Clinical Chemistry, 18, 199-202.

[31] Reitman, A. and Frankel, S. (1957) Determination of serum glutamic oxaloacetic and glutamic pyruvic transaminase. American Journal of Clinical Pathology, 28, 56-63.

[32] Dumas, B.T., Watson, W.A. and Biggs, H.G. (1971) Albumin standard and measurment of serum albumin with bromocresol. Clinica Chimica Acta, 258, 21-30. doi:10.1016/S0009-8981(96)06447-9

[33] Beutler, E., Duron, O. and Kelly, M.B. (1963) Improved method for the determination of blood glutathione. Journal of Laboratory and Clinical Medicine, 61,882-888.

[34] Stocks, J. and Dormandy, T.L. (1971) The autoxidation of human red cell lipids induced by hydrogen peroxide. British Journal of Haematology, 20, 95-111. doi:10.1111/j.1365-2141.1971.tb00790.x

[35] Nishikimi, M., Roa, N.A. and Yagi, K. (1972) The occurence of superoxide anion in the reaction of reduced phenazine methosulfate and molecular oxygen. Biochemical and Biophysical Research Communications, 46, 849854. doi:10.1016/S0006-291X(72)80218-3

[36] Drakin, D.L. and Austin, J.H. (1932) Spectrophotometric constants for common hemoglobin derivatives in human, dog, rabbit blood Journal of Biological Chemistry, 98, 19-68.

[37] El-Aaser, A.A. and El-Merzabani, M.M. (1975) Simultaneous determination of 5'-nucleotidase and alkaline phosphatase. Zeitschrift für Klinische Chemie und Klinische Biochemie, 13, 453-459.

[38] Szasz, G., Rosenthal, P. and Fritzsche, W. (1969) Gamma glutamyl transpeptidase activity in the serum in hepatobiliary diseases. Deutsche Medizinische Wochenschrift, 94, 1911-1917. doi:10.1055/s-0028-1110364

[39] Berkels, R., Purol-Schnabel, S. and Roesen, R. (2004) Measurment of nitric oxide by reconversion of nitrate/nitrite to NO. Methods in Molecular Biology, 279, 1-8.

[40] Borchers, A.T., Stern, J.S., Hackman, R.M., Keen, C.L. and Gershwin, E.M. (1999) Mushrooms, tumors, and immunity. Proceedings of the Society for Experimental Biology and Medicine, 221, 281-293. doi:10.1046/j.1525-1373.1999.d01-86.x

[41] Park, P.-J., Je, J.-Y. and Kim, S.-K. (2004) Free radical scavenging activities of different deacetylated chitosans using an ESR spectrometer. Carbohydrate Polymers, 55, 17-22.

[42] Kathiriya, A., Das, K., Kumar, E.P. and Mathai, K.B. (2010) Evaluation of antitumor and antioxidant activity of oxalis corniculata linn. Against ehrlich ascites carcinoma on mice. Iranian Journal of Cancer Prevention, 3, 65157.

[43] Kalaiselvi, M., Narmadha, R., Ragavendran, P., Ravikumar, G., Gomathi, D., Sophia, D., Raj, C.A., Uma, C. and Kalaivani, K. (2011) In vivo and in vitro antitumor activeity of jasminum sambac (linn) alt oleaceae flower against daltons ascites lymphoma induced swiss albino mice. International Journal of Pharmacy and Pharmaceutical Sciences, 4, 145-147.

[44] Mazumder, U.K., Prerona, S., Haldar, P.K., Naskar, S., Kundu, S., Bala, A. and Kar, B. (2011) Anticancer activeity of methanol extract of cucurbita maxima against herlich ascites carcinoma. International Journal of Pharmaceutical Sciences, 2, 52-59.

[45] Fouda Fatma, M. (2005) Anti-tumor activity of tetrodotoxin extracted from the Masked Puffer fish Arothron diadematus. Journal of Biology, 7, 1-13.

[46] Deepa, P.R. and Varalakshmi, P. (2003) Protective effect of low molecular weight heparin on oxidative injury and cellular abnormalities in adriamycin-induced cardiac and hepatic toxicity. Chemico-Biological Interactions, 146, 201210. doi:10.1016/j.cbi.2003.08.003

[47] Fahim, F.A., Esmat, A.Y., Mady, E.A. and Ibrahim, E.K. (2003) Antitumor activities of iodo acetate and dimethylsulphoxide against solid ehrlich carcinoma growth in mice. Biological Research, 36, 253-262. doi:10.4067/S0716-97602003000200015

[48] Duh, P.D., Du, P.C. and Yen, G.C. (1999) Action of methanolic extract of mung bean hulls as inhibitors of lipid peroxidation and non-lipid oxidative damage. Food and Chemical Toxicology, 37, 1055-1061. doi:10.1016/S0278-6915(99)00096-4

[49] Crespy, V. and Williamson, G. (2004) A review of the health effects of green tea catechins in vivo animal model. Journal of Nutrition, 134, 3431-3440.

[50] Kaklamani, V.G., Hou, N., Bian, Y., Reich, J., Offit, K., Michel, L.S., Rubinstein, W.S., Rademaker, A. and Pasche, B. (2003) $T G F B R 1 * 6 \mathrm{~A}$ and cancer risk: A meta-analysis of seven case-control studies. Journal of Clinical Oncology, 21, 3236-3243. doi:10.1200/JCO.2003.11.524

[51] Benckert, C., Jonas, S., Cramer, T., Von Marschall, Z., Schafer, G., Peters, M., Wagner, K., Radke, C., Wiedenmann, B., Neuhaus, P., Hocker, M. and Rosewicz, S. (2003) Transforming growth factor $\beta 1$ stimulates vascular endothelial growth factor gene transcription in human cholangiocellular carcinoma cells. Cancer Research, 63, 10831092.

[52] Suzuki, K., Tokoro, A., Okawa, Y., Suzuki, S. and Suzuki, M. (1986) Effect of N-acetylchitooligosaccharideson activation of phagocytes. Microbiology and Immunology, 30, 777-787.

[53] El-Far, M., Elshal, M., Refaat M. and El-Sherbiny, I.M. (2011) Antitumor activity and antioxidant role of a novel water-soluble carboxymethyl chitosan-based copolymer. Drug Development and Industrial Pharmacy, 37, 14811490. doi:10.3109/03639045.2011.587430 


\section{ABBREVIATIONS}

ALB, albumin; ALK-P, alkaline phosphatase; ALT, alanine transaminase; AST, aspartate transaminase; DNA, deoxy ribonucleic acid; EAC, ehrlich ascites carcinoma; GGT, gamma glutamyl transferase; GSH, reduced glutathione; $\mathrm{H}_{2} \mathrm{O}_{2}$, hydrogen peroxide; $\mathrm{HB}$, hemoglobin; LD50, medial lethal dose; MDA, malondialdehyde; PLT, platelets; RBCs, red blood cells; RNA, ribonucleic acid; ROS, reactive oxygen species; SA-CMC, stearic acid grafted carboxymethyl chitosan; SOD, superoxide dismutase; TGF- $\beta$, transforming growth factor- $\beta$; VEGF, vascular endothelial growth factor; WBCs, white blood cells. 